\title{
Indigeneity, Colonial History and Truth
}

In 2019, indigenisation of tertiary settings in Aotearoa seems to have taken twenty steps back over as many years where the systemic nature of our colonial history continues to determine what counts. Māori continue to sit on the outside of what is the norm within mainstream tertiary institutions or at best within pockets of various forms within it. ${ }^{1}$ Indigeneity insists that Māori did not cede sovereignty. ${ }^{2}$ For indigeneity to be realised, the place of Māori as tangata whenua needs to be apparent in the systems that govern us and the decisions that affect us.

As indigenous peoples, Māori cut a track some time ago; however, the institutions governed and managed by our Treaty partners have not done so well in keeping pace. A continued resistance to 'things Māori' pervades where there is a sense of the mainstream always looking to recoup resources they may have lost to Māori-led initiatives. This is just one aspect of the white-streaming that occurs in the context of indigenous experience in Aotearoa and in the diminishment of Te Tiriti o Waitangi responsibilities to Māori within the sector. ${ }^{3}$

This writing speaks to the spaces, places, people and times associated with the land that Unitec Institute of Technology, Te Whare Wananga o Wairaka, as a tertiary institution is built-on, Rangimatarau. From a Māori view of the world, we acknowledge the land that sustains us. As tertiary organisations develop roadmaps to assist in navigating through and around the tertiary landscape, we need also be mindful of where we stand, in standing on this land.

Essentially, this roadmap needs to acknowledge both the history and the people of these lands and how we might best determine a future that is meaningful and purposeful for all. In saying this, as Māori, we assert our rights as tangata whenua ${ }^{4}$ and reject any notion that considers Māori as a minority grouping. Just as non-Māori need to acknowledge this, so too do the decision-makers leading tertiary organisations and those in government.

The kōrero presented in this writing, offers a Māori view of where 'indigeneity' sits in the current experience of working in tertiary institutions that have been plagued by continual restructuring within a sector that seems to not know what to do with itself. With a keen focus on using neoliberal, business model approaches within educational settings, ${ }^{5}$ the sector has lost its way, losing focus of what counts, which is learning and people. 
Constant restructuring, aside from causing complete disarray, has incurred a murky culture of uncertainty and mistrust. ${ }^{6}$ Though there are undertakings of improvement, they tend to be intermittent and subject to a tendency to revert to embedded practices. This consistent restructuring is a major distraction to progressing Māori aspirations in the tertiary space.

Since the signing of Te Tiriti o Waitangi, Māori are all too familiar with this scenario where we have been inter-generationally marginalised through the processes of education ${ }^{7}$ within a colonial system that has systematically rejected the very idea that Māori have our own knowledge systems or science.

Māori sciences lie in the land, the sky and the universe. ${ }^{8}$ The flow of the river, the change of seasons and the food sources that this brings, our star systems and moon calendar are all sciences of earth and sky, our ecosystems and life. The seen and the unseen world. The sciences of our ancestors recognises also there exists a spirit or energetic fields that link through time and space beyond the physical aspects of the natural world to that world of a meta-physical nature. ${ }^{9}$ Acknowledgment and understanding of the spiritual dimension of people and their connections to place and 'being' is significant in making sense of the relationships between people and their environments.

Spirituality or wairua is integral to Māori knowledge systems and world-views. With the introduction of Mason Durie's Te Whare Tapawha model, ${ }^{10}$ huge in-roads to understanding spirituality as important to holistic well-being have been well established in many services. Despite this, practices associated with wairua and the intangible nature of spirituality are more than often considered by mainstream as lacking credibility. ${ }^{11}$

For indigeneity to exist within mainstream educational settings, these settings need to acknowledge the spirituality and life force of all things. The whenua (land) in particular, holds huge significance in Te Ao Māori and indigenous knowledge systems ${ }^{12}$ in that it is part of our indigenous identity. ${ }^{13}$

In understanding that the land holds vast memories of the past and that connection to the land is intrinsic to our being, we know also that the spirit-world is ever-present. Te Ao Māori acknowledges the spiritual nature of all things in our natural world, as well as in our holistic make-up as human beings. ${ }^{14}$

\section{KARANGA TE AO}

When our biosphere calls for collaboration, do we as educators actually hear? How do we ensure that we are connected and culturally competent for community practice? How are staff and students encouraged to apply Te Tiriti o Waitangi in practice and reflect the values of Te Noho Kotahitanga, the guiding values of this institution?

For students, connection is a priority for their success in learning, regardless of where in the world they are from. Students learning without preparation of cultural or spiritual knowledge are basically unprepared.

How does our teaching enable Māori students the opportunity to realign their approaches and development of belief systems from Western constructs? How do we encourage students more 
generally to be able to incorporate validation of their own identities in their philosophical and theoretical approaches to strengthen and foster diversity and acceptance within actual practice?

\section{POWHIRI}

Powhiri is a powerful example of how we share our protocols and practices. The process of powhiri is both cultural and spiritual. It is important for all newcomers to our institution and can often be the first interaction of its kind for many, New Zealanders and international students alike. International students who come here express their feeling that the process of powhiri allows spiritual connection to this place (personal communications), to Unitec but also to this whenua Aotearoa.

Powhiri provides them with a sense of belonging as it guides students through a process that weaves people, ancestors and place. For our staff and students to walk this process with every orientation builds trust and a sense of belonging. For students, having an appreciative understanding of our sciences through connecting to our environment can widen their understanding of our culture through powhiri, through tikanga; our guidelines, and kawa, our processes. Only through the applied practice of tikanga and kawa, matauranga Māori actioned through the process of powhiri, do some of our staff and students experience glimpses into, and feel, the true essence of our world.

Tertiary organisations have consistently failed to recognise the real significance of our indigenous practices and knowledge, as a holistic contribution to the well-being of not only Māori, but of all people. Powhiri weaves all these aspects of our environment in the welcoming of sacred feet/ waewae tapu to the land. The process is spiritual and vital to a holistic view based within cultural knowledge. This experience is especially important in working towards a realistic, sustainable future. $^{15}$

While powhiri is a regular part of tertiary institutional practice in Aotearoa and has been for a long time, it is important that knowledge and appreciation of spirituality are not relegated to ceremonial practice, but are applicable to wider settings across tertiary organisation. A further challenge is to strengthen and legitimise understanding of spirituality as a human science within institutional knowledge and practice.

\section{WHAT'S IN A NAME?}

The name, Unitec Institute of Technology, has its historical roots in the polytechnic sector and the trades. The significance of trade training is undeniably the beginnings of the Institution of Technology and Polytechnic (ITP) sector, a system of apprenticeship bought here from England where apprentices trained alongside skilled tradesmen. In New Zealand, the trades have traditionally attracted Pākehā males, although from the 1950s, efforts targeted Māori through highly successful trades training schemes. By the 1980s, interest in the trades generally waned when degree level qualifications were preferred at the time. ${ }^{16}$ Vocational educational training ${ }^{17}$ has nevertheless made a comeback over the last decade or so where trades are recognised as highly desirable, although they are also acknowledged as rapidly changing to include the dynamic of high level automation and robotics technology. 
The naming of Unitec as Te Whare Wānanga o Wairaka has its roots in the history of the land. Side by side, these names illustrate a sense of conflict or contradiction in that they represent very different things. Those differences nevertheless are representative of the truth of their foundations, of their purpose where both have relevance to this institution. This is a constant reality for the organisation, highlighting that the origin of Unitec has both Māori and Pākehā histories: histories of love and war, inter-tribal disputes and rivalry, settlement and cultivation, alienation, mental instability, disease, loss, distress, betrayal, power and abuse. These histories are in Unitec's wharehui, Ngakau Mahaki; illustrated in the carvings, and shared in the kōrero of those who carry the knowledge of the whare and the land.

Te Whare Wānanga o Wairaka, by name, acknowledges Wairaka, ancestress of Mataatua waka as significant to this place and in her making her place in these lands. The history associated with Wairaka long precedes European settlement. Acknowledged as a rangatira and a leader, Wairaka exercised the power of women to take action, to determine and define.

Rangimatarau as an ancient place of learning hosted wānanga for wahine. ${ }^{18}$ It was an ancient school of learning for women and girls that nurtured the sciences of Papatuanuku, with ancient wisdoms encouraged and applied through practice. As an ancient place of learning, the land on which we sit has a legacy of learning to be realised.

These learnings are based in truth where the histories of these lands are spoken. That is, the colonial systems that have denied this country's true history where the education system has systematically eroded Māori knowledge systems, all the while embedding white privilege in its institutions. Privilege as such has existed for near-on 180 years in terms of who holds power and the control of education, and indeed, of society more generally. Indigenisation of tertiary settings in Aotearoa requires organisational practice to be located on foundations of truth, of both Pākehā history and Māori history. Conversations based in truth are an important part of dismantling and decolonising colonial discourses responsible for the miseducation of New Zealanders.

All students have a right to learn and importantly, a right to learn the truth about our own histories. The right to truthful knowledge of this country's colonial history continues to face denial ${ }^{19}$ where millions of New Zealanders have been, and continue to be, educated in a system that has concealed not only its colonial history but also the on-going impact of colonisation on its indigenous peoples. The inability of New Zealand society to address its history reflects an avoidance to face its past; ${ }^{20}$ a past where extreme violence, cultural superiority, discrimination, greed and racism are absent from the teachings of settler history.

\section{THE 'R' WORD}

The realisation of racism existing in Aotearoa today has been discussed more recently and openly by mainstream New Zealand following the tragic occurrence of the March 15, 2019 shootings in Christchurch, when 51 people of the Muslim faith died as a result of being shot in their places of prayer. While the country reeled in shock as many of us thought such an incident as this would not occur in this country, our colonial history tells us otherwise. ${ }^{21}$

As a country, we have seen a keen aversion to discussing racism. Talk of racism upsets the framing of New Zealand as a harmonious nation. It undoes our international image of unity. It unravels the work of those who have always held power. It unearths the racism that has driven colonisation 
across the globe. When we refuse to acknowledge our history as a country in which its colonial systems have devastated its indigenous population, ${ }^{22}$ there is much to be said. While much of the current debate highlights the rise of white supremacy, when we look at the history of colonial settlement in this country, cultural dominance and white superiority sit at the very core of New Zealand's nationhood. Though the reluctance to talk about it may seek to erase memories of past injustices, forgetting is not an option. In moving forward, we look back to Te Tiriti o Waitangi, to navigate our way. It is our roadmap.

\section{TE TIRITI O WAITANGI}

As an agreement made between Māori and the Crown, Te Tiriti o Waitangi grounds us in the understanding of rangatira who signed, and their belief that Māori would share power and authority with the Crown as equals. ${ }^{23}$ All historical taonga, inclusive of genetic bloodlines, spirituality and cultural wisdoms, ${ }^{24}$ are expressed in Te Tiriti o Waitangi. Of significance, prior to the signing of Te Tiriti o Waitangi in 1840, is the preceding document, the 1835 He Whakaputanga, Declaration of Independence (O'Malley, 2017), ${ }^{25}$ which is important in terms of rangatira declaring Aotearoa as a confederation of sovereign peoples at the time.

The biggest transgression in our history has been the non-compliance by subjects of the Crown to Te Tiriti o Waitangi where an acute disregard of Te Tiriti o Waitangi has been passed down through generations. The importance and standing of Te Tiriti o Waitangi is implicit in raising discussion around the denial of our colonial history.

In working towards implementing the intent of Te Tiriti, the importance of working as treaty partners is critical as a nation that respects its history and honours its future. Pākehā need be active participants in this process. While general understanding of Te Tiriti is both mixed and varied, its intent as an agreement between peoples holds responsibilities for both parties.

The way forward need not be complex. Working from a place that seeks justice, truth and equity is the Treaty in action. Treaty activist and lawyer, Moana Jackson asserts the Treaty as being about the "rightness that comes from people accepting their obligations to each other." ${ }^{26} \mathrm{~A}$ future, that values what is right and just, is dependent on the willingness to hold to such obligation.

\section{TE NOHO KOTAHITANGA}

A unique aspect of Te Whare Wānanga o Wairaka is the Te Noho Kotahitanga principles, Rangatiratanga, Wakaritenga, Kaitiakitanga, Mahi Kotahitanga and Ngākau Māhaki. These principles acknowledge an organisational commitment to Te Tiriti o Waitangi as a working partnership with tangata whenua. How is this practised in reality? Although Te Noho Kotahitanga is heralded as significant within Unitec, the failure to apply holistic cultural understanding of it actively has been absent.

To be clear, indigeneity will only occur within mainstream tertiary institutions when the Treaty partner wants it and actively pursues it, working as an active partner with tangata whenua. While Unitec is in a position to perfect a model of practice drawing from Te Noho Kotahitanga principles, this can only be actioned with Māori sharing leadership as Treaty partners. The Tertiary Education Union's Te Pou Tuarā, Lee Cooper, suggests that if tertiary institutions are serious about 
addressing inequities in tertiary education outcomes that the sector generally looks to recognising the importance of Māori leadership. ${ }^{27}$ In-depth knowledge of Māori concepts and knowing how to apply them within practice is a requirement for this leadership where belief in our own knowledge, systems and practices is critical to those leading.

In the 'transformation' phase of restructuring, ${ }^{28}$ an aversion to truthful, respectful and honest relationships also impeded the potential of a robust and vibrant organisational culture. Over what has been a long period of restructuring, trust has completely eroded. To rebuild trust requires truthful, honest and respectful relationships across the organisation, where Unitec's values of Te Noho Kotahitanga provide direction. It is suggested, however, that the implementation of the following principles requires further wānanga to provide a specific set of guidelines to ensure a thorough organisational uptake.

Rangatiratanga: Authority and Responsibility

E whakarite ana te Whare Wānanga o Wairaka ki te putake ake o te rangatiratanga o te Māori me ngā matauranga Māori.

Unitec accepts the principle that Māori have authority over and responsibility for all teaching and learning relating to the Māori dimensions of knowledge.

Wānanga: In taking the principle a step further, in being self-determining, we are responsible for our actions where responsibility is both individual and collective.

Wakaritenga: Legitimacy

E whakarite ana te Whare Wānanga o Wairaka ki te mana o tēnā, o tēnā, ki te noho kotahi, ki te puaki i tōnā ake reo, ki te whakamahi i ngā rawa mo ngā iwi katoa.

Unitec believes that each partner has a legitimate right to be here, to speak freely in either language, and to put its resources to use for the benefit of all.

Wānanga: Concepts of whakaritenga relate to agreement, negotiation, implementation, appointments and utilising Te Tiriti o Waitangi with truth of application. The focus is on equal participation in decision-making.

Kaitiakitanga: Guardianship

E whakarite ana te Whare Wānanga o Wairaka ki te kaitiakitanga o ngā taonga matauranga.

Unitec accepts responsibility as a critical guardian of knowledge.

Wānanga: The role of kaitiakitanga works actively to protect and ensure the integrity of knowledge. Kaitiakitanga is implicitly linked to the land and waterways, to the natural world and our ecosystems.

Mahi Kotahitanga: Co-operation

E whakarite ana te Whare Wānanga o Wairaka kia tau he ngākau māhaki i roto i ngā mahi katoa.

Unitec affirms that a spirit of generosity and co-operation will guide all its actions. 
Wānanga: Working in unity, together, for the benefit of collective good. It acknowledges both Māori and Crown Subjects advancing in unity with truthful intent.

Ngākau Māhaki: Respect

E whakarite ana te Whare Wānanga o Wairaka ki te whakanui i ngā taonga tuku iho o ngā ao e rua, a hikoi ki mua.

Unitec values each partner's heritage and customs, with Māori and Pākehā working together to address current needs and future aspirations.

Wānanga: Humility, compassion and respect in truth is required to ensure equality and equity are actioned in practice.

\section{WĀNANGA}

The groundwork of Te Noho Kotahitanga principles have been well-cemented in the efforts undertaken by those involved in and around the marae complex, and specifically so with the Maia Centre over the last two decades. While the process of restructuring has taken its toll on an initiative that worked well for Māori, ${ }^{29}$ the partnership needs to be activated in meaningful ways for change to occur. Te Noho Kotahitanga principles require wānanga to ensure guidelines will be purpose fit for the organisation, staff and students. This requirement includes a definition of 'tauiwi' to note the diversity of our student body and staffing as significant within the principles of Te Noho Kotahitanga.

\section{TE NOHO KOTAHITANGA MARAE}

At this institution sits our Marae, the manifestation of the principles by the same name, Te Noho Kotahitanga Marae. It provides a framework that has the ability to guide our practice purely by the names given to our marae complex that welcomes all staff and students to this place.

Te Waiunuroa o Wairaka - the long thirst of Wairaka is an ancient spring that flows through campus, and reminds us that the thirst for knowledge is lifelong.

Rangimarie - peace is where staff and students find a place of solitude in the flax garden; it reminds us to centre ourselves and reconnect with our natural environment when the energies of learning and technology become erratic.

Puukenga - a repository of knowledge, it acknowledges the skills that staff and students bring and with them their own cultural identity.

Manaaki - our dining room reminds us to nurture and grow all aspects of each other where our students can also become our teachers.

Ngakau Mahaki - the respectful heart our wharenui, it reminds us all to be compassionate, to be humble and respectful of each other. 
A model of practice when integrated with the principles of the same name ensures unity that has the potential for indigenous wisdom within our students and staff to evolve and emerge with a frequency and vibration of holistic freedom to sciences of the soul, found within the spirit of Te Tiriti o Waitangi.

\section{KARANGA TE PO}

The night calls, we are at a precipice in time: known and unknown resistance, conflict and resolution, interdisciplinary relationships between science and spirituality. Te Po encourages action, creation, a birthing of new ideas and evolutionary manifestation of whanaungatanga, relational connectivity to purposeful higher learning and the ways in which we practice. ${ }^{30}$

In tertiary institutions, we must recognise that the impact of colonisation and intergenerational disconnection through lack of spiritual, cultural and historical knowledge leaves a trail of crises in its wake. Intergenerational post-colonial traumatic stress disorder ${ }^{31}$ is real in terms of the impacts on both staff and students within tertiary institution.

Students are impacted by feelings of spiritual and cultural incompetence and loss. Māori, in particular, express a sense of whakama or embarrassment and shame. International students or students of ethnic backgrounds also speak of loss in terms of disconnection and isolation (personal communications). Staff also experience bouts of inadequacy and sometimes feel out of their depth in certain situations, when not knowing how to respond or react.

Sometimes, staff put our students at risk through resistance to our cultural practices and thinking that they are able to implement our ways of knowing and doing without engaging with us when they send their students to the 'Māori' place on campus. This lack of wisdom highlights a huge gap in not only common sense but also in etiquette. In resisting our cultural knowledge, our spirituality and ways of knowing and doing, the questions asked are: What do you actually have to offer? Where is the partnership? Why are you here? A crisis our students experience is the right to know, to get it right; their learning is disjointed by staff who have chosen to remain ignorant of our pedagogies. In order for our students to be competent practitioners in all facets of industry and community practice, they require a holistic education. This is an internal debate that highlights the struggle within the education system to find sustainable models of teaching and learning, inclusive of cultural competency. Gaps exist when departments consistently work in silos, which enables and embeds resistance to cultural change, through the lack of spiritual and cultural knowledge and understanding. The impact is a lack of unity, co-operation and whakawhanaungatanga within the organisation. ${ }^{32}$

Ignorance or tolerating the situation is no excuse, turning a blind eye, a deaf ear, being closedmouthed, making excuses that allows the resistance to continue, makes one complicit in maintaining the status quo of white privilege,$^{33}$ and in accommodating practices of hegemony ${ }^{34}$ that maintain colonial systems and ways of thinking. These afflictions exist and are encouraged at all levels of society - masked as equal opportunity to achieve and maintain positions of dominance while denying systems of dominance exist. ${ }^{35}$ 
Cultural knowledge and practices have the ability to ensure real change is able to take place rather than further embed hegemonic practices. It can be daunting to face up to the truth; however, Māori have waited 179 years for truth to surface. Facing one's fear can be as daunting as facing up to the truth. The possibility of working as Treaty partners, sharing power and authority is central to the discussion of indigeneity. It will require sacrifice and courage to integrate truth into the foundational aspects of policies, legislation and practice. ${ }^{36}$ Aotearoa has a responsibility to continue to make change in all aspects of foundational processes. To cover up untruth is no longer an option.

\section{INDIGENEITY}

The discussion of the place of indigeneity within a mainstream tertiary organisation has raised some of the conflicts around the foundations of truth relating to the histories of the land and the place of this history in our tertiary organisations. Highlighted also is the ongoing resistance to Māori knowledge systems, as both spiritual and scientific knowledge has yet to be accepted and validated within these settings. Movement towards a future that honours Te Tiriti o Waitangi in its entirety where Māori share power and authority in all decisions that impact on Māori, situates indigeneity in a place that demands change. Nearly two hundred years later, it is time for our Treaty partners to catch up.

We need to ensure our mechanisms are constantly improving and our solutions focussed. In spite of government reforms, with more boxes to tick and hoops to jump through, our institutions must work towards building on sound foundations of historical truth.

The work to action Te Noho Kotahitanga principles and Te Tiriti o Waitangi is a constant. It requires a commitment to equality and equity by all staff to achieve a balance of energetic transcendence. We need to connect, listen, learn, share, though sometimes stumbling in the process, embracing the good, the bad and the ugly that is all our past. This ensures our students and staff evolve and emerge with a frequency and vibration of holistic freedom to sciences of the soul, found within the spirit of Te Tiriti o Waitangi.

Rangimatarau significantly connects our students to sacred place and sacred space so that we may all journey together under the one Sun, under the one Moon, regardless of where one originated in the world..$^{37}$ For all those who walk on this land, your sacred footsteps are forever mingled with those of tangata whenua, a sacred memory on the land. When you leave here, you will leave behind your sacred imprints, imprinted forever in the frequencies and vibrations throughout time in this place, in this space, on this land, Rangimatarau. 
Ko Whareorino ratou ko Maungaroa ko Te Puke Hokioi, ko Te Tihi o Te Ao Marama ngā maunga

Ko Waikawau rātou ko Marokopa ko Mangapu ngā awa

Ngā Tai o Raukura Te Moana

Ko Tainui Te Waka

Ko Ngati Maniapoto Te Iwi

Ko Ngati Kinohaku rātou ko Ngati Te Kanawa ko Ngati Peehi ngā Hapū

Ko Tawapiko Te Papakainga, ko Mirumiru rāua ko Oparure ngā Marae

Ko Miromiro i Te Po rātou ko Waipatoto Tuatahi, ko Waipatoto Tuarua ngā Wharenui

Ko Miromiro i Te Awatea rāua ko Te Tihi o Te Ao Marama ngā Wharekai

Ko Lynda Toki tōku ingoa.

Lynda Toki, a student since 2001 having completed a Master of Applied Practice earlier this year, is also Kaiawhina Student Support and Kuia/Ruruhi at Te Noho Kotahitanga Marae, Unitec Institute of Technology. She is enriched by Māori sciences that lie within the land, shared through storytelling nga taonga i tuku iho, treasures handed down throughout the generations, acknowledging and understanding the spiritual dimension of people and their connections to place and space, in order to make sense of the relational aspects between people and their environment.

She is also motivated by the Institution's commitment to Te Tiriti o Waitangi through their own Treaty with Māori, in the values and principles that acknowledge a Partnership, also called Te Noho Kotahitanga. Lynda is committed to the Tauira and Kaimahi that make up this amazing community also known as Te Whare Wananga o Wairaka.

Ko Whakarongorua te maunga

Ko Utakura te awa

Ko Hokianga te moana

Ko Mokonuiarangi me Mataitaua ngā marae

Ko Te Popoto me Ngatitoro ngā hapū

Ko Ngapuhi nui tonu te iwi

Ko Ngatokimatahaorua te waka

Ko Jo Mane tōku ingoa

Jo Mane - I am of Ngapuhi whakapapa and have worked with post-graduate students undertaking the Masters of Applied Practice with Unitec over the last two years and continue to supervise Master's students at Unitec. I have four adult children and six mokopuna, all who have been or are schooled in kaupapa Māori settings. I have worked extensively in the Far North working in the field of community development and education and also in tertiary education. My primary research approach is kaupapa Māori; however, I also draw on critical theory and community based research approaches.

My key research interests are kaupapa Māori research, Māori education and Māori development. I currently work as part of a research team with, community based research organisation, Wai Research. 
1. Helen Potter and Lee Cooper, Project Whitestreaming: A report on the generalising of Māori specialist staff positions in the tertiary education sector (Wellington, New Zealand: Tertiary Education Union, 2016).

2. Māori Law Review, "Waitangi Tribunal finds Treaty of Waitangi signatories did not cede sovereignty in February 1840" (November, 2014), https:// maorilawreview.co.nz/2014/11/waitangi-tribunalfinds-treaty-of-waitangi-signatories-did-not-cedesovereignty-in-february-1840/

3. Potter and Cooper, Project Whitestreaming, (2016). Ann Milne, "Colouring in the White Spaces: Reclaiming Cultural Identity in Whitestream Schools" (PhD thesis, University of Waikato, 2013).

4. J Mane, "He Reo Tautoko: A History of Iwi Radio Broadcasting" (Unpublished Master's thesis, University of Auckland, 2000).

5. Tertiary Education Union, “Submission to the Productivity Commission: Inquiry into new models for tertiary education" (2016), https:// www.productivity.govt.nz/assets/SubmissionDocuments/dc74289e72/Sub-083-TertiaryEducation-Union.pdf

6. Tertiary Education Union, "Submission to the Productivity Commission." David Cooke, "Blind Faith: Deconstructing Unitec 2015-2017", (Wellington: Tertiary Education Union, 2018).

7. Ranginui Walker, Ka Whawhai Tonu Matou: Struggle Without End (Auckland: Penguin, 2004). Judith Simon, and Linda Tuhiwai Smith eds., A Civilising Mission? Perceptions and Reflections of the New Zealand Native Schools System. (Auckland: Auckland University Press, 2001).

8. M King ed., Te Ao Hurihuri: Aspects of Māoritanga. (New Zealand: Raupo Publishing, 1993). Māori Marsden, The Woven Universe: Selected Writings of Rev. Māori Marsden edited by Te Ahukaramū Charles Royal (Otaki: Estate of Rev. Māori Marsden, 2003).

9. King, Te Ao Hurihuri, (1993). Marsden, The Woven Universe. Tuakana Mate Nepe, Te Toi Huarewa tipuna: Kaupapa Māori, an educational intervention system. (Unpublished Master's thesis, Auckland. New Zealand: University of Auckland, 1991). Lesley Rameka, "He Ira Atua: The Spiritual Spark of the Child" He Kupu: The Word 4, no. 2, October (2015): 82-92, https://www.hekupu. ac.nz/article/te-ira-atua-spiritual-spark-child
10. Mason Durie, "Te Whare Tapa Wha": A Māori Philosophy toward health is underpinned by four dimensions: Te taha hinengaro (Psychological health) Te taha wairua (Spiritual health) Te taha tinana (physical health) Te taha whanau (Family health) (1984). Retrieved from https://www. careers.govt.nz/assets/pages/docs/Final-careertheory-model-te-whare-tapa-wha-20170501.pdf

11. Vivienne Kennedy et al., "Wairua and Cultural Values in Evaluation" Evaluation Matters-He Take Tō Te Aromatawai 1 (2015): 83-111, https:// www.nzcer.org.nz/nzcerpress/evaluation-matters/ articles/wairua-and-cultural-values-evaluation

12. Suzanne Romaine, "The Impact of Language Policy on Endangered Languages" International Journal on Multicultural Societies, 4, no. 2 (2002): 194212.

13. Hirini Moko Mead, and Neil Grove, Ngā Pēpeha a ngā Tipuna: The Sayings of the Ancestors (Wellington: Victoria University Press 2001). Linda Te Aho, "Tikanga Māori, historical context and the interface with Pākehā law in Aotearoa/New Zealand" New Zealand Yearbook of New Zealand Jurisprudence 10, (2007):10, http://www8.austlii. edu.au/nz/journals/NZYbkNZJur/2007/4.html

14. Durie, "Te Whare Tapa Wha."

15. Marsden, The Woven Universe.

16. Tertiary Education Commission - Retrieved from https://www.tec.govt.nz/assets/ Reports/2e3edec3c0/TEC-report-Background-forfirst-discussion-about-ITP-viability.pdf

17. Helen Anderson and Lisa Maurice-Takerei, (Vocational Education in Aotearoa New Zealand, (New Zealand: Dunmore Publishing, 2015).

18. D Foley, J Brarr, and L Toki, Oral conversations: Memory Recalls of the Land, presentation (Unitec Institute of Technology, April 2007).

19. Vincent O'Malley, The New Zealand Wars: Ngā Pakanga o Aotearoa (Wellington: Bridget Williams Books, 2019), Introduction.

20. Ibid.

21. M Jackson, (2018) Understanding racism in this country. Retrieved from https://e-tangata. co.nz/comment-and-analysis/moana-jacksonunderstanding-racism-in-this-country/ and Jackson, Moana. (2018) School to Prison Pipeline: Education, Systemic Racism and Issues of Incarceration for Māori, Aboriginal and African American Youth. Pre-Conference Workshops. Auckland University of Technology. 12 November 2018. 
22. Jackson, Understanding racism.

23. He Whaka putanga me te Tiriti, The Declaration and the Treaty, The Report on Stage 1 of the Te Pararahi o Te Raki inquiry, Wai 1040, Waitangi Tribunal Report, 2014. Retrieved from https:// forms.justice.govt.nz/search/Documents/WT/wt_ DOC_85648980/Te\%20RakiW_1.pdf, 202.

24. Rangimarie Turuki Arikirangi Rose Pere, Te Wheke: A Celebration of Infinite Wisdom (Ao Ako Global Learning NZ Ltd, 2003). Mead, and Grove, Ngā Pēpeha a ngā Tipuna. Te Matorohanga, Te Kauwae Runga Whare Wananga Booklet; na H.T. Whatahoro i tuhituhi nga korero a Te Matorohanga, 1885.

25. Vincent O'Malley, He Whakaputanga: The Declaration of Independence, 1835 (Wellington: Bridget Williams Books, 2017).

26. National Library of New Zealand, "Interview with Moana Jackson" He Tohu interview, 2016 40:35, https://natlib.govt.nz/he-tohu/korero/interviewwith-moana-jackson

27. Tertiary Education Union, “You can't be aspirational if you begin with a deficit approach", May 31, 2019. Retrieved from https://teu.ac.nz/news/you-cantbe-aspirational-if-you-begin-with-a-deficit-approach

28. Cooke, "Blind Faith: Deconstructing Unitec 20152017", (TEU, Aug 2018), in Dulcie-Jane Brake “Doing More With Less': A critical analysis of ideological discourse in tertiary sector policy documents and its impact on polytechnics in New Zealand" (2019). Retrieved from https://openrepository.aut. ac.nz/bitstream/handle/10292/12935/BrakeDJ. pdf?sequence $=3 \&$ isAllowed $=y$
29. Unitec Institute of Technology, Te Noho Kotahitanga and Unitec, 2018, Retrieved from https://www. unitec.ac.nz/about-us/te-noho-kotahitanga-andunitec

30. D H Ingvar, " "Memory of the future": an essay on the temporal organization of conscious awareness" Human Neurobiology, 4 no. 3 (1985): 127-136. Marsden, The Woven Universe. Pere, Te Wheke. Cleve Barlow, Tikanga Whakaaro: Key concepts in Māori Culture (Auckland: Oxford University Press, 1991). Rohana Ulluwishewa, Spirituality Demystified: Understanding Spirituality in Rational Terms (Palmerston North: Sairon Books Ltd, 2015).

31. Miron Dolot, Execution by Hunger: The Hidden Holocaust (New York: W.W. Norton \& Company, 1987).

32. Marsden, The Woven Universe. Pere, Te Wheke. Ulluwishewa, Spirituality Demystified.

33. Peggy Mclntosh, "White Privilege: Unpacking the Invisible Knapsack", in Seed, The National SEED Project, 1989, Retrieved from https:// nationalseedproject.org/Key-SEED-Texts/whiteprivilege-unpacking-the-invisible-knapsack

34. Gramsci, Antonio, Selections from the Prison notebooks of Antonio Gramsci edited and translated by Quintin Hoare and Geoffrey Nowell Smith. (London: Lawrence \& Wishart, 1971).

35. Mclntosh, "White Privilege".

36. Marsden, The Woven Universe. Pere, Te Wheke. Ulluwishewa, Spirituality Demystified.

37. Marsden, The Woven Universe. 